\title{
Dynamic intuitionistic fuzzy multi-attribute aftersales performance evaluation
}

\author{
Sezi Çevik Onar ${ }^{1} \cdot$ Basar Oztaysi $^{1} \cdot$ Cengiz Kahraman $^{1}$
}

Received: 14 March 2017 / Accepted: 20 June 2017 / Published online: 4 July 2017

(C) The Author(s) 2017. This article is an open access publication

\begin{abstract}
Aftersales services are crucial for gaining a competitive advantage, since they enhance long-term profitability and sustainability. Aftersales service performance evaluation is necessary to understand current problems and develop new strategies. Multi-period evaluations are required for revealing these performances. Moreover, performance appraisal results usually involve uncertainty and fuzziness. In this study, a dynamic intuitionistic fuzzy multi-attribute aftersales performance evaluation method is used to measure the performance of an electronics company. A sensitivity analysis is conducted to examine the robustness of the results.
\end{abstract}

Keywords Dynamic intuitionistic · Fuzzy $\cdot$ Performance evaluation $\cdot$ Aftersales $\cdot$ Multi-criteria

\section{Introduction}

Aftersales services include various activities that start after the purchasing of the product or service and continue during the usage of the product or service $[3,9,36]$. Aftersales services provide a competitive advantage by enabling companies to differentiate the product or service and increase the revenue by sale of spare parts. Therefore, aftersales services are considered as the linkage between customers and the company [9]. Customer preferences and an initial selection of customers differ based on the provided products or services and the additional services after pur-

Sezi Çevik Onar

cevikse@itu.edu.tr

1 Industrial Engineering, Istanbul Technical University, Macka, Istanbul 34367, Turkey chasing the product or service $[25,44]$. Maintaining customer satisfaction, improving the quality, providing wellmaintained relationships with customers, increasing customer satisfaction and loyalty, and enhancing competitive advantage are the main objectives of aftersales services $[3,14,36]$.

Performance evaluation is the key to a successful aftersales service system. To have a comprehensive aftersales performance evaluation system, the evaluation process should involve both objective and subjective performance evaluation criteria collected at different periods. The nature of aftersales performance evaluation criteria usually consists of uncertainty and vagueness. Fuzzy sets are perfect tools for dealing with the vagueness and uncertainty. Intuitionistic fuzzy sets are the fuzzy sets that enable defining both membership and non-membership values. This definition enables a better representation of ambiguity and vagueness to inherit in performance criteria. Therefore, in this study, a dynamic intuitionistic fuzzy multi-attribute decision-making method is used for dealing with this fuzzy multi-stage evaluation process. To the best of our knowledge, this study is the first paper that develops an aftersales performance appraisal system using dynamic intuitionistic fuzzy sets. It also provides a sensitivity framework for better understanding the evaluations and checking the robustness of the results.

The rest of this paper is organized as follows: section "Aftersales performance" summarizes aftersales performance evaluation systems in the literature. Section "Dynamic intuitionistic fuzzy multi-attribute decision-making" presents basic concepts of the dynamic intuitionistic fuzzy sets. In the section "Aftersales Service Performance Measurement", aftersales service performance of an electronics company is measured. The last section concludes the paper and gives some perspectives.

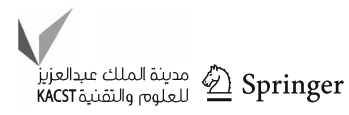




\section{Aftersales performance}

Installation, training, routine maintenance, emergency repair, spare parts supply, and software services are primary activities in the aftersales services [39]. These services also include transport or delivery, installation, user training, documentation, advice by helpdesk, technical advice, maintenance and repair, online report, warranty, spare part delivery, recycling, and upgrades $[12,13,16,32,36]$. In addition to these lists of activities, aftersales services include call center operations, home visiting services, and claim handling services [1].

Measurement of performance in aftersales services is quite important to understand current problems and develop strategies. Gaiardelli et al. [15] claim that literature has limited well-prepared performance measurement systems for aftersales services and develop performance measurement system for aftersales services. According to this study, there should be various levels of analysis depending on the purposes. Moreover, there should be a combination of financial and non-financial dimensions, long-term and short-term decisions, tangible and intangible features, and measures of the efficiency and effectiveness.

According to Baileyt et al. [6], the flexibility of services, the reliability of company and personnel, and expectations of customers about the service have an influence on the customer satisfaction. Matzler et al. [27] claim that reliability and friendliness of personnel affect customer satisfaction. Birgelen et al. [7] reveal that customization, flexibility, recovery, and spontaneous customer delight affect customer satisfaction by influencing from technological developments. The evaluation system includes four different levels of business, process, activity, and development and innovation [15]. At the business level, the overall performance of aftersales services is measured by operating profit, Return on Investment (ROI), and Return on Assets (ROA) for services based on the revenue and cost. At the process level, performance measurement is done based on the customer satisfaction, flexibility, and productivity. Flexibility evaluates the satisfaction level of customer expectations from the external and internal point of view. External point of view reflects customers view, while the internal point of view is about the company itself. Ahn and Sohn [1] determine all of the activities in the aftersales services necessitate usage easiness, reaching speed, technical skills, management speed, assurance, and politeness for having satisfied customers. Sadeghi and Hanzaee [34] claim that accessibility, convenience, accuracy, security, usefulness, and brand image affect the customer satisfaction. Krishnan and Hari [24] list important factors of customer satisfaction as easiness of repair, overall quality, product compatibility, the price of the product and service, worthiness, reliability, usage experience, and responsiveness. Rahman (2014) also state that innovativeness of services, competitiveness, reliability, consistency, and price of products and services influence the customer satisfaction. Performance measurement system of aftersales services in the literature can be classified into nine main categories namely, Customer Satisfaction (CS), Service Quality (SQ), Financial Success (FS), Perceived Service Value (PV), Customer Retention (CR), Repurchase (R), Brand Loyalty (BL), Recommendation (R), and Brand Image (BI).

\section{Customer satisfaction (CS)}

Customer satisfaction is one of the most important key concepts of performance measurement. Customer satisfaction shows the perception of customers about the product or service of the company. It is the result of a comparison between customer expectations and perceived performance of product or service [24].

Customer satisfaction is the customers' reaction to the contradiction between expectations and experienced performance of a product or a service [37]. When customer satisfaction level is enhanced $1 \%$, return on investment value is enhanced $2.37 \%$ on average, since satisfied customers tend to purchase new products or services and this leads to reaching financial success [22]. Customer satisfaction is meeting the expectations of customers or performing more than their expectations while performing services [19]. Krishnan and Hari [24] statistically show that cost of attracting a new customer for purchasing product or service of the company is ten times larger than the cost of keeping an existing customer. Satisfied customers tend to share their experiences with other people. According to [23], customer satisfaction has the essential meaning for companies as a tool for reaching important aspects. Customer satisfaction has importance due to both financial and operational advantages. Customer satisfaction is affected by various attributes, and it is important regarding having loyal customers, increasing long-term financial performance, profitability, and market share of the companies [35]. Customer satisfaction is crucial to the success of businesses in both economic and strategic aspects.

\section{Service quality (SQ)}

Service quality is another important attribute of aftersales services performance. Service quality is the comparison of expected performance level of services with perceived performance of services. Parasuraman et al. [28] develop SERVQUAL dimensions and state that there are ten dimensions affecting service quality as reliability, responsiveness, competence, access, courtesy, communication, credibility, security, understanding the customer, and tangibles. Parasuraman et al. [29] decrease these ten factors to five as reliability, responsiveness, security, understanding the customer, and tangibles. 


\section{Financial success (FS)}

The financial success of aftersales services is mainly determined based on the calculations of profit, cash flow, ROI, and ROA of companies regarding the costs and revenue [15]. It is one of the main goals of companies and departments. Most of the elements have small or large effects on the financial success.

\section{Perceived service value (PSV)}

Perceived service value determines the value of product and service based on the perception of customers. According to [20], perceived service value is defined by comparing inputs and outputs of a service where inputs include attributes related to the customers and outputs include attributes related to the aftersales service of the company. It is the comparison of benefits from the service and sacrifices of customers to get this service such as price, time, and effort [33].

\section{Customer retention (CR)}

Customer retention is keeping customers to purchase products and services of companies. According to Lindgreen et al. [26], attracting a new customer is ten times more expensive than keeping an existing customer. Therefore, companies give importance to customer retention instead of trying to get new customers. Customer retention provides an increase in the revenue of the companies, because retained customers increase the quantity of sold products [8,30]. Griffin [17] states that a little increase in customer retention provides as much as $25 \%$ increase in the profits. Thus, retained customers are important, since they tend to spend more money for the company and share their experiences.

\section{Repurchase (RP)}

Repurchase is keeping purchasing the products and services offered by the company. It is about the satisfaction level of customers and customer retention of companies. If customers are satisfied with the aftersales services of companies, they tend to stay as a customer of the same company, and keep buying other products and aftersales services of the company [18].

\section{Brand loyalty (BL)}

Brand loyalty is an emotional relationship between customers and company. Anderson and Srinivasan [2] declare that dissatisfied customers highly tend to go to competitors. Thus, customer satisfaction affects the brand loyalty of customers and brand loyalty leads to customer retention.

\section{Recommendation (RC)}

Recommendation is the advice of customers to other customers on the products and services of a company [31]. It has a significant impact on the customer behaviors. Most of the customers start purchasing activities based on the recommendations of previous customers of the company.

\section{Brand image (BI)}

Brand image is the current perception of customers on a company. It is the position of the company in their customers' minds. This intangible and inimitable element of the company is one of the most important attributes for aftersales performance and customer satisfaction. Brand image is affected by reliability, professionalism, and innovativeness of company, having a social contribution and giving value to the customers [38].

\section{Dynamic intuitionistic fuzzy multi-attribute decision-making}

Intuitionistic fuzzy sets are the fuzzy sets that consider both the membership and non-membership values for defining fuzziness in a system. The sum of membership and nonmembership values of an intuitionistic fuzzy set is less than or equal to one $[4,5]$. In the literature, they are widely used to represent fuzziness in different areas $[21,42,43]$, Onar et al. $(2015,2016)$.

\section{Preliminaries}

Definition 1 An intuitionistic fuzzy set in a given set $X(X \neq$ $\emptyset)$ is an object $\tilde{I}$ given by

$\tilde{I}=\left\{\left\langle x, \mu_{\tilde{I}}(x), v_{\tilde{I}}(x),\right\rangle ; x \in X\right\}$,

where $\mu_{\tilde{I}}: X \rightarrow[0,1]$ and $v_{\tilde{I}}: X \rightarrow[0,1]$ satisfy the condition

$0 \leq \mu_{\tilde{I}}(x)+v_{\tilde{I}}(x) \leq 1$,

for every $x \in X$ where $\mu_{\tilde{I}}(x)$ is the membership value and $v_{\tilde{I}}(x)$ is the non-membership value of intuitionistic fuzzy set $\tilde{I}$.

Definition 2 A dynamic intuitionistic fuzzy variable that has a time dimension can be defined as $\widetilde{I(t)}=\left(\mu \widetilde{I(t)}, v_{I(\tilde{t})}, \pi \widetilde{I(t)}\right)$, where $t$ is a time variable [40]:

$\mu_{\alpha(t)}+v_{\alpha(t)} \leq 1, \pi_{\alpha(t)}=1-\mu_{\alpha(t)}-v_{\alpha(t)}$ 
Table 1 Intuitionistic fuzzy decision matrix collected at four quarters

\begin{tabular}{|c|c|c|c|c|c|c|c|c|c|}
\hline & $\mathrm{CS}$ & SQ & FS & PSV & $\mathrm{CR}$ & $\mathrm{RP}$ & BL & $\mathrm{RC}$ & BI \\
\hline \multicolumn{10}{|l|}{ t1 } \\
\hline P1 & $(0.8,0.1,0.1)$ & $(0.8,0.1,0.1)$ & $(0.4,0.5,0.1)$ & $(0.9,0.1,0)$ & $(0.7,0.2,0.1)$ & $(0.5,0.2,0.3)$ & $(0.7,0.2,0.1)$ & $(0.3,0.1,0.6)$ & $(0.5,0.3,0.2)$ \\
\hline $\mathrm{P} 2$ & $(0.9,0.1,0)$ & $(0.8,0.1,0.1)$ & $(0.4,0.2,0.4)$ & $(0.9,0.1,0)$ & $(0.8,0.1,0.1)$ & $(0.5,0.3,0.2)$ & $(0.6,0.2,0.2)$ & $(0.7,0.1,0.2)$ & $(0.3,0.1,0.6)$ \\
\hline P3 & $(0.1,0.7,0.2)$ & $(0.1,0.7,0.2)$ & $(0.8,0.2,0)$ & $(0.5,0.2,0.3)$ & $(0.6,0.4,0)$ & $(0.6,0.2,0.2)$ & $(0.7,0.2,0.1)$ & $(0.9,0.1,0)$ & $(0.4,0.4,0.2)$ \\
\hline P4 & $(0.3,0.6,0.1)$ & $(0.8,0.1,0.1)$ & $(0.1,0.6,0.3)$ & $(0.9,0.1,0)$ & $(0.7,0.2,0.1)$ & $(0.7,0.2,0.1)$ & $(0.5,0.4,0.1)$ & $(0.8,0.2,0)$ & $(0.4,0.4,0.2)$ \\
\hline P5 & $(0.4,0.5,0.1)$ & $(0.4,0.1,0.5)$ & $(0.1,0.9,0)$ & $(0.6,0.2,0.2)$ & $(0.6,0.2,0.2)$ & $(0.4,0.2,0.4)$ & $(0.4,0.3,0.3)$ & $(0.5,0.2,0.3)$ & $(0.6,0.3,0.1)$ \\
\hline \multicolumn{10}{|l|}{ t2 } \\
\hline $\mathrm{P} 1$ & $(0.8,0.1,0.1)$ & $(0.5,0.1,0.4)$ & $(0.7,0.1,0.2)$ & $(0.8,0.1,0.1)$ & $(0.6,0.2,0.2)$ & $(0.9,0.1,0)$ & $(0.7,0.3,0)$ & $(0.5,0.2,0.3)$ & $(0.3,0.3,0.4)$ \\
\hline $\mathrm{P} 2$ & $(0.7,0.1,0.2)$ & $(0.1,0.6,0.3)$ & $(0.4,0.4,0.2)$ & $(0.1,0.7,0.2)$ & $(0.3,0.6,0.1)$ & $(0.1,0.2,0.7)$ & $(0.7,0.1,0.2)$ & $(0.3,0.3,0.4)$ & $(0.9,0.1,0)$ \\
\hline P3 & $(0.8,0.2,0)$ & $(0.1,0.8,0.1)$ & $(0.1,0.8,0.1)$ & $(0.2,0.1,0.7)$ & $(0.2,0.7,0.1)$ & $(0.3,0.3,0.4)$ & $(0.8,0,0.2)$ & $(0.4,0.2,0.4)$ & $(0.5,0.1,0.4)$ \\
\hline P4 & $(0.5,0.4,0.1)$ & $(0.7,0,0.3)$ & $(0.5,0.2,0.3)$ & $(0.4,0.2,0.4)$ & $(0.9,0,0.1)$ & $(0.9,0,0.1)$ & $(0.8,0.1,0.1)$ & $(0.9,0.1,0)$ & $(0.4,0,0.6)$ \\
\hline P5 & $(0.6,0.2,0.2)$ & $(0.9,0,0.1)$ & $(0.8,0.1,0.1)$ & $(0.3,0.6,0.1)$ & $(0.1,0.1,0.8)$ & $(0.5,0.4,0.1)$ & $(0.5,0.4,0.1)$ & $(0.8,0.2,0)$ & $(0.9,0.1,0)$ \\
\hline \multicolumn{10}{|l|}{$\mathrm{t} 3$} \\
\hline $\mathrm{P} 1$ & $(0.6,0.1,0.3)$ & $(0.4,0.4,0.2)$ & $(0.3,0.7,0)$ & $(0.7,0.1,0.2)$ & $(0.9,0,0.1)$ & $(0.4,0.4,0.2)$ & $(0.8,0.1,0.1)$ & $(0.7,0.2,0.1)$ & $(0.4,0.4,0.2)$ \\
\hline $\mathrm{P} 2$ & $(0.2,0.4,0.4)$ & $(0.5,0.1,0.4)$ & $(0.8,0.2,0)$ & $(0.9,0.1,0)$ & $(0.4,0.1,0.5)$ & $(0.6,0.2,0.2)$ & $(0.7,0.2,0.1)$ & $(0.6,0.2,0.2)$ & $(0.6,0.4,0)$ \\
\hline P3 & $(0.6,0.1,0.3)$ & $(0.6,0.2,0.2)$ & $(0.3,0.4,0.3)$ & $(0.6,0.3,0.1)$ & $(0.1,0.8,0.1)$ & $(0.6,0.3,0.2)$ & $(0.6,0.1,0.3)$ & $(0.8,0.1,0.1)$ & $(0.5,0.2,0.3)$ \\
\hline P4 & $(0.7,0.1,0.2)$ & $(0.9,0.1,0)$ & $(0.6,0.2,0.2)$ & $(0.7,0.2,0.1)$ & $(0.6,0.1,0.3)$ & $(0.8,0.1,0.1)$ & $(0.7,0,0.3)$ & $(0.5,0.2,0.3)$ & $(0.6,0.3,0.1)$ \\
\hline P5 & $(0.7,0.1,0.2)$ & $(0.6,0.3,0.1)$ & $(0.9,0.1,0)$ & $(0.3,0.6,0.1)$ & $(0.7,0.1,0.2)$ & $(0.4,0.4,0.2)$ & $(0.9,0,0.1)$ & $(0.9,0,0.1)$ & $(0.5,0.2,0.3)$ \\
\hline \multicolumn{10}{|l|}{$\mathrm{t} 4$} \\
\hline $\mathrm{P} 1$ & $(0.9,0.1,0)$ & $(0.9,0.1,0)$ & $(0.7,0.1,0.2)$ & $(0.6,0.2,0.2)$ & $(0.8,0.1,0.1)$ & $(0.7,0.1,0.2)$ & $(0.6,0.2,0.2)$ & $(0.3,0.6,0.1)$ & $(0.8,0,0.2)$ \\
\hline $\mathrm{P} 2$ & $(0.2,0.2,0.6)$ & $(0.9,0.1,0)$ & $(0.2,0.8,0)$ & $(0.6,0.3,0.1)$ & $(0.6,0.1,0.3)$ & $(0.4,0.4,0.2)$ & $(0.6,0.1,0.3)$ & $(0.6,0.2,0.2)$ & $(0.9,0,0.1)$ \\
\hline P3 & $(0.9,0.1,0)$ & $(0.3,0.6,0.1)$ & $(0.3,0.6,0.1)$ & $(0.3,0.7,0)$ & $(0.7,0.1,0.2)$ & $(0.5,0.4,0.1)$ & $(0.7,0,0.3)$ & $(0.7,0.1,0.2)$ & $(0.7,0.1,0.2)$ \\
\hline $\mathrm{P} 4$ & $(0.1,0.1,0.8)$ & $(0.4,0.5,0.1)$ & $(0.2,0.3,0.5)$ & $(0.2,0.1,0.7)$ & $(0.4,0.1,0.5)$ & $(0.5,0.2,0.3)$ & $(0.6,0.3,0.1)$ & $(0.8,0.2,0)$ & $(0.8,0.2,0)$ \\
\hline P5 & $(0.7,0.1,0.2)$ & $(0.4,0.3,0.3)$ & $(0.3,0.6,0.1)$ & $(0.8,0.1,0.1)$ & $(0.1,0.5,0.4)$ & $(0.8,0.2,0)$ & $(0.8,0.1,0.1)$ & $(0.9,0.1,0)$ & $(0.5,0.4,0.1)$ \\
\hline
\end{tabular}

where $\mu_{I(t)} \in[0,1]$ is the membership value, $v_{I(t)} \in[0,1]$ is the non-membership value, and $\pi_{\alpha(t)} \in[0,1]$ is the hesitancy value of dynamic intuitionistic fuzzy variable $\widetilde{I(t)}$.

Definition $3 \widetilde{I\left(t_{1}\right)}, \widetilde{I\left(t_{2}\right)}, \ldots, \widetilde{I\left(t_{n}\right)}$ are the intuitionistic fuzzy numbers collected at $\mathrm{n}$ different periods [8].

Definition 4 Let $\widetilde{I\left(t_{1}\right)}=\left(\mu \widetilde{I\left(t_{1}\right)}, v \widetilde{I\left(t_{1}\right)}, \pi \widetilde{I\left(t_{1}\right)}\right)$ and $\widetilde{I\left(t_{2}\right)}=$ $\left(\mu \widetilde{I\left(t_{2}\right)}, v \widetilde{I\left(t_{2}\right)}, \pi \widetilde{I\left(t_{2}\right)}\right)$ be the values of intuitionistic fuzzy variable $\widetilde{I(t)}$ taking $t=t_{1}, t_{2}$.

Then,

$\widetilde{I\left(t_{1}\right)} \oplus \widetilde{I\left(t_{2}\right)}=\left(\mu \widetilde{I\left(t_{1}\right)}+\mu \widetilde{I\left(t_{2}\right)}-\mu \widetilde{I\left(t_{1}\right)} \mu \widetilde{I\left(t_{2}\right)}\right.$,

$\left.v \widetilde{I\left(t_{1}\right)} v \widetilde{I\left(t_{2}\right)},\left(1-\mu \widetilde{I\left(t_{1}\right)}\right)+\left(1-\mu \widetilde{I\left(t_{2}\right)}\right)-v \widetilde{I\left(t_{1}\right)} v \widetilde{I\left(t_{2}\right)}\right)$

$\lambda \widetilde{I\left(t_{1}\right)}=\left(1-\left(1-\mu \widetilde{I\left(t_{1}\right)}\right)^{\lambda}\right.$

$\left., v \frac{\lambda}{I\left(t_{1}\right)},\left(1-\mu \widetilde{I\left(t_{1}\right)}\right)^{\lambda}-v \frac{\lambda}{I\left(t_{1}\right)}\right), \quad \lambda>0$

where $\lambda$ is a scalar.
Definition 5 Let $t_{k}$ denote the kth period and $\omega_{t_{k}}$ is the weight at the $t_{k}$ th period, where $t=t_{1}, t_{2}, \ldots, t_{n}$ and $\omega(t)=\left(\omega\left(t_{1}\right), \omega\left(t_{2}\right), \ldots, \omega\left(t_{n}\right)\right)$ istheweightvector with $\left(t_{n}\right) \in[0,1], \quad \sum_{k=1}^{p} \omega\left(t_{k}\right)=1$.

\section{Dynamic intuitionistic fuzzy multi-attribute decision-making}

Dynamic intuitionistic fuzzy multi-attribute decision-making method developed by [41] deals with the intuitionistic fuzzy values collected at different periods. The steps of this methodology are given as follows:

- Defining the attributes and evaluating alternatives for the problem.

- Evaluating each alternative $i$ with respect to each attribute $j$ using intuitionistic fuzzy numbers for each period $t_{k}$ :

$\tilde{I}_{i j}\left(t_{k}\right)=\left(\mu_{i j}\left(t_{k}\right), v_{i j}\left(t_{k}\right), \pi_{i j}\left(t_{k}\right)\right.$

where $\tilde{I}_{i j}\left(t_{k}\right)$ is the intuitionistic fuzzy evaluation for alternative $i=1,2, \ldots, n$ and attribute $j=1,2, \ldots, m$ at period $t_{k}$. 
Table 2 Complex intuitionistic fuzzy decision matrix

\begin{tabular}{llllll}
\hline & CS & SQ & FS & PSV & CR \\
\hline P1 & $(0.813,0.1,0.087)$ & $(0.747,0.152,0.101)$ & $(0.585,0.211,0.204)$ & $(0.722,0.132,0.146)$ & $(0.806,0,0.194)$ \\
P2 & $(0.466,0.2,0.334)$ & $(0.73,0.143,0.127)$ & $(0.516,0.4,0.084)$ & $(0.73,0.229,0.041)$ & $(0.529,0.143,0.328)$ \\
P3 & $(0.783,0.14,0.077)$ & $(0.362,0.464,0.174)$ & $(0.351,0.504,0.145)$ & $(0.412,0.325,0.263)$ & $(0.478,0.316,0.206)$ \\
P4 & $(0.439,0.158,0.403)$ & $(0.727,0,0.273)$ & $(0.401,0.263,0.336)$ & $(0.543,0.141,0.316)$ & $(0.654,0,0.346)$ \\
P5 & $(0.659,0.135,0.206)$ & $(0.629,0,0.371)$ & $(0.688,0.255,0.057)$ & $(0.599,0.263,0.138)$ & $(0.403,0.204,0.393)$ \\
\hline & RP & BL & RC & BI & $(0.608,0,0.392)$ \\
\hline P1 & $(0.688,0.162,0.15)$ & $(0.702,0.176,0.122)$ & $(0.492,0.29,0.218)$ & $(0.816,0,0.184)$ \\
P2 & $(0.434,0.275,0.291)$ & $(0.654,0.132,0.214)$ & $(0.565,0.202,0.233)$ & $(0.585,0.141,0.274)$ \\
P3 & $(0.511,0.323,0.166)$ & $(0.698,0,0.302)$ & $(0.727,0.115,0.158)$ & $(0.658,0,0.342)$ \\
P4 & $(0.738,0,0.262)$ & $(0.673,0,0.327)$ & $(0.771,0.174,0.055)$ & $(0.646,0.239,0.115)$ \\
P5 & $(0.627,0.283,0.09)$ & $(0.782,0,0.218)$ & $(0.865,0,0.135)$ & \\
\hline
\end{tabular}

Table 3 Closeness coefficient

\begin{tabular}{llll}
\hline & $\sum_{j=1}^{m} \gamma_{j}\left(1-v_{i j}\right)$ & $\sum_{j=1}^{m} \gamma_{j}\left(1+\pi_{i j}\right)$ & $\begin{array}{l}\text { Closeness } \\
\text { coefficient }\end{array}$ \\
\hline P1 & 0.864 & 1.179 & 0.733 \\
P2 & 0.808 & 1.204 & 0.671 \\
P3 & 0.741 & 1.196 & 0.620 \\
P4 & 0.918 & 1.296 & 0.709 \\
P5 & 0.847 & 1.191 & 0.711 \\
\hline
\end{tabular}

- Calculating the weight vector for periods $\omega(t)=$ $\left(\omega\left(t_{1}\right), \omega\left(t_{2}\right), \ldots, \omega\left(t_{p}\right)\right)$ using arithmetic series based method (Xu 2008) where the difference between $\omega\left(t_{k}\right)$ and $\omega\left(t_{k+1}\right)$ is a constant $c$ :

$\omega\left(t_{k+1}\right)-\omega\left(t_{k}\right)=c, \quad \omega\left(t_{k}\right)=\eta+(k-1) c$

where when all the weights are equal, $c=0, \eta=$ $\frac{1}{n}, \omega\left(t_{k}\right)=\frac{1}{n}(k=1,2, \ldots, p)$,

when $\omega\left(t_{k}\right)$ is a monotonically increasing sequence, $c>$ 0 then $\omega\left(t_{k}\right)<\omega\left(t_{k+1}\right)$, when $\omega\left(t_{k}\right)$ is a monotonically decreasing sequence $c<0$ then $\omega\left(t_{k}\right)>\omega\left(t_{k+1}\right)$.

In this study, the weights are assumed to be equal.

- Aggregating the Intuitionistic numbers collected at different periods with dynamic weighted fuzzy averaging (DIFWA) operator [41].

$$
\begin{aligned}
& \widetilde{D I F W} A_{\omega(t)}^{\left(\tilde{I}\left(t_{1}\right), \tilde{I}\left(t_{2}\right), \ldots, \tilde{I}\left(t_{n}\right)\right)} \\
& =\left(1-\prod_{k=1}^{n}\left(1-\mu_{\tilde{I}\left(t_{k}\right)}\right)^{\omega\left(t_{k}\right)}, \prod_{k=1}^{n} v_{\tilde{I}\left(t_{k}\right)}^{\omega\left(t_{k}\right)}\right. \\
& \left.\quad \times \prod_{k=1}^{n}\left(1-\mu_{\tilde{I}\left(t_{k}\right)}\right)^{\omega\left(t_{k}\right)}-\prod_{k=1}^{n} v_{\tilde{I}\left(t_{k}\right)}^{\omega\left(t_{k}\right)}\right)
\end{aligned}
$$

- Defining the intuitionistic fuzzy ideal $Y^{+}=\left(I_{1}^{+}, I_{2}^{+}\right.$, $\left.\ldots, I_{m}^{+}\right)^{T}$ and negative ideal solutions $Y^{+}=\left(I_{1}^{-}\right.$, $\left.I_{2}^{-}, \ldots, I_{m}^{-}\right)^{T}$, where $I_{i}^{+}=(1,0,0)$ is the largest and $I_{i}^{-}=(0,1,0)$ is the smallest Intuitionistic fuzzy numbers.

- Calculating the closeness coefficient of each alternative using Eq. (8) and selecting the alternative with the highest closeness coefficient:

$$
C_{i}=\frac{\sum_{j=1}^{m} w_{j}\left(1-v_{i j}\right)}{\sum_{j=1}^{m} w_{j}\left(1+\pi_{i j}\right)},
$$

where $i=1,2, \ldots, n$ and $w_{j}$ is the weight of the $j$ th attribute

\section{Aftersales service performance measurement}

An electronics company that outsources its aftersales services wants to measure the performance of the aftersales provider companies. The company has five different aftersales providers. These aftersales providers' performance can be measured by the attributes Customer Satisfaction (CS), Service Quality (SQ), Financial Success (FS), Perceived Service Value (PSV), Customer Retention (CR), Repurchase (RP), Brand Loyalty (BL), Recommendation (RC), and Brand Image (BI). A group of three managers evaluated five different aftersales providers. The managers discuss their evaluations and achieve final compromise evaluations collectively. The performances of the aftersales service providing companies are evaluated at four periods. Table 1 shows the compromised intuitionistic fuzzy decision matrix collected at these four periods.

The newer periods have a bigger impact on the performance evaluation. Therefore, the weights of periods are determined by the arithmetic series. The weight of the 
Fig. 1 Sensitivity analysis

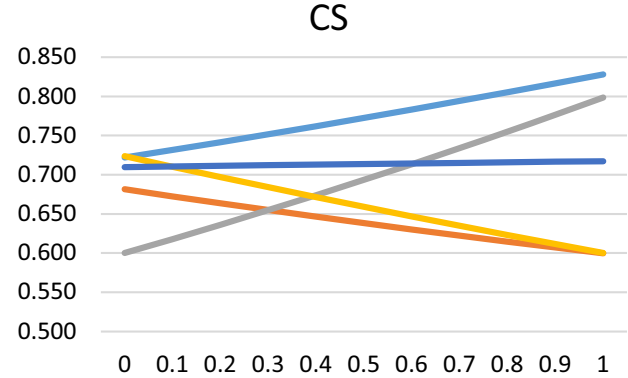

FS
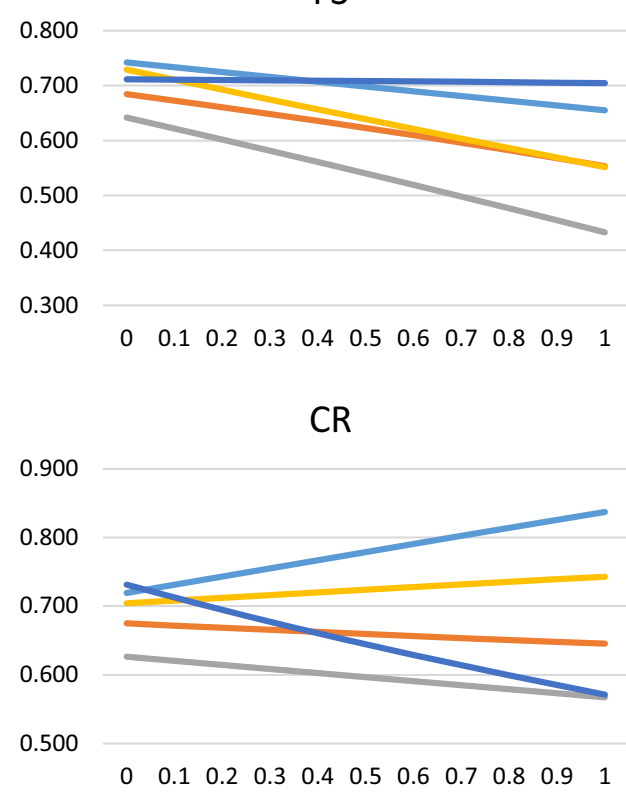

BL

0.850
0.800
0.750
0.700
0.650
0.600
0.550
0.500

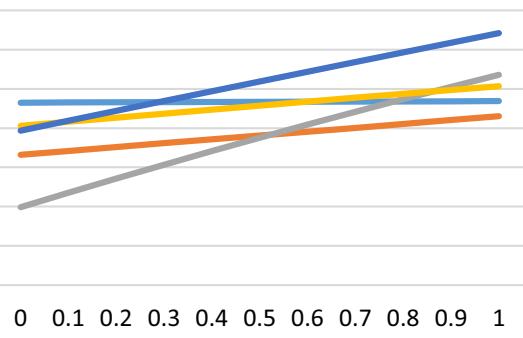

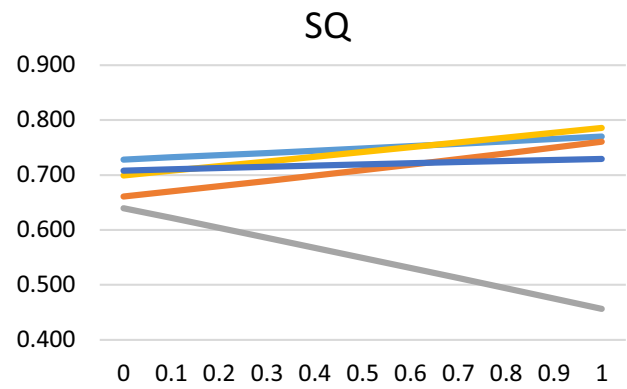

PSV
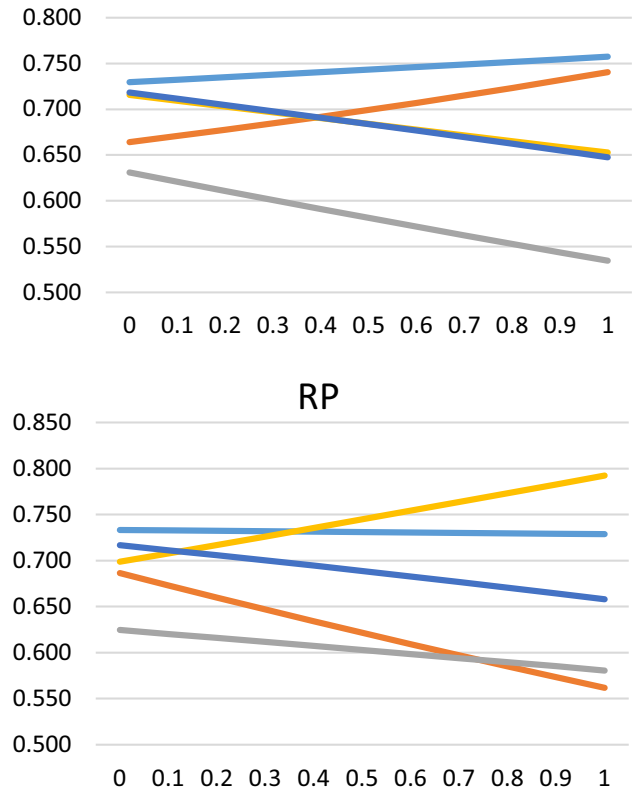

$\mathrm{RC}$

1.000

0.900

0.800

0.700

0.600

0.500

$\begin{array}{lllllllllll}0 & 0.1 & 0.2 & 0.3 & 0.4 & 0.5 & 0.6 & 0.7 & 0.8 & 0.9 & 1\end{array}$

BI

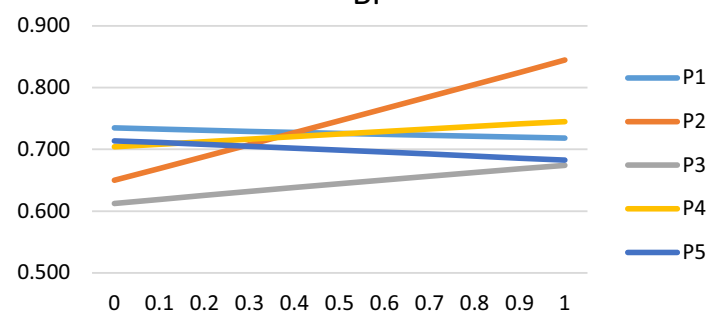

periods are defined as follows: $\omega\left(t_{1}\right)=0.1 ; \omega\left(t_{2}\right)=$ $0.2 ; \omega\left(t_{3}\right)=0.3 ; \omega\left(t_{4}\right)=0.4$. Using Eq. (7), the intuitionistic fuzzy evaluations given in Table 1 are aggre- gated into complex intuitionistic fuzzy decision matrix (Table 2). 
All the attributes have the same importance. Using Eq. (8), the closeness coefficient of each alternative is calculated (Table 3).

$\mathrm{P} 1$ has the highest performance, whereas the $\mathrm{P} 3$ aftersales services provider has the lowest performance. The managers of the study revealed that they are satisfied with the results.

To reveal the robustness of the results, a one at a time sensitivity analysis is conducted. Figure 1 shows the results of the sensitivity analysis. In this analysis, the weights of the attributes are changed, and the change in the closeness coefficient is measured.

The performances of aftersales companies are changing depending on the weights of the attributes. The performances are highly responsive to the change in the attributes. Currently, P1 shows the highest performance among aftersales provider companies mainly due to its performance on Customer Satisfaction, Perceived Service Value, and Customer Retention criteria. However, P5 becomes the leading aftersales provider when the importance of Financial Success is higher than 0.4 , or the importance of Recommendation is greater than 0.2 or the importance of Brand Loyalty is greater than 0.3 . P4 becomes the highest performing aftersales provider when Service Quality is almost only performance criteria or when the importance of repurchase is higher than 0.4. P2 becomes the leading aftersales provider when the brand image is more important than 0.5 .

\section{Conclusion}

In this study, the performances of aftersales performance providers of an electronics company are measured with a dynamic aftersales performance measurement system. Customer Satisfaction (CS), Service Quality (SQ), Financial Success (FS), Perceived Service Value (PSV), Customer Retention (CR), Repurchase (RP), Brand Loyalty (BL), Recommendation (RC), and Brand Image (BI) are the main factors for the measurement process. The evaluations are collected at four different periods. These intuitionistic fuzzy evaluations are aggregated with the dynamic intuitionistic fuzzy multi-attribute decision-making method. The first provider shows the highest performance, whereas the third provider has the worst performance. The performance scores of the providers change when the weights of attributes are changed.

In this study, a new dynamic performance evaluation system is developed. This proposed performance evaluation system uses intuitionistic fuzzy sets for evaluating the performance of aftersales companies. Since intuitionistic fuzzy sets use both membership and non-membership values, they provide a more realistic approach for revealing the evaluations of decision makers. The method also enables collecting information at various times and aggregating them without losing information. The decision makers are satisfied with the results and willing to use the method in the future. The developed sensitivity analysis framework provides a better understanding of the results. Other companies that deal with aftersales providers can use the proposed method.

For further research, instead of the intuitionistic fuzzy sets, other extensions of fuzzy sets such as interval-valued intuitionistic fuzzy sets, Pythagorean fuzzy sets, or triangular intuitionistic fuzzy sets can be used.

Open Access This article is distributed under the terms of the Creative Commons Attribution 4.0 International License (http://creativecomm ons.org/licenses/by/4.0/), which permits unrestricted use, distribution, and reproduction in any medium, provided you give appropriate credit to the original author(s) and the source, provide a link to the Creative Commons license, and indicate if changes were made.

\section{References}

1. Ahn JS, Sohn SY (2009) Customer pattern search for after-sales service in manufacturing. Expert Syst Appl 36:5371-5375

2. Anderson RE, Srinivasan SS (2003) E-satisfaction and e-loyalty: a contingency framework. Psychol Mark 20:123-138

3. Asl MA, Tolarod MM (2015) An overview of service quality within an after sales service industry: commercial vehicles. Thesis (Master), Lulea University of Technology, Sweden

4. Atanassov K (1986) Intuitionistic fuzzy sets. Fuzzy Sets Syst 20:87-96

5. Atanassov K (1999) Intuitionistic fuzzy sets. Theory and applications. Physica, Heidelberg

6. Baileyt JE, Pearson SW (1983) Pearson development of a tool for measuring and analyzing computer user satisfaction. Manage Sci 25:530-545

7. Birgelen MV, Ruyter KD, Jong AD, Wetzels M (2002) Customer evaluations of after-sales service contact modes: an empirical analysis of national culture's consequences. Int J Res Mark 19:43-64

8. Buttle F (1996) SERVQUAL: review, critique, research agenda. Eur J Mark 30:8-32

9. Cavalieri S, Gaiardelli P, Ierace S (2007) Aligning strategic profiles with operational metrics in after-sales service. Int J Prod Perform Meas 56:436-455

10. Cevik Onar S, Oztaysi B, Otay I, Kahraman C (2015) Multi-expert wind energy technology selection using interval-valued intuitionistic fuzzy sets. Energy 90(1):274-285

11. Cevik Onar S, Oztaysi B, Kahraman C (2016) Aftersales service performance measurement using dynamic intuitionistic fuzzy multi-attribute decision making. In: Proceedings of the 12th international FLINS conference, pp 845-850, August 24-26, 2016, Roubaix, France

12. Choudhary AI, Akhter SA, Asif M, Choudhry RM, Siddique Z, Mughal A (2011) Impact of after sale service characteristics on customer satisfaction. Inf Manag Bus Rev 3:360-365

13. Deveraj S, Matta KF, Conlon E (2001) Product and service quality: the antecedents of customer loyalty in the automotive industry. Prod Oper Manag 10:424-439

14. Fazlzadeh A, Bagherzadeh F, Mohamadi P (2011) How after-sales service quality dimensions affect customer satisfaction. Afr J Bus Manag 5:7658-7664

15. Gaiardelli P, Saccani N, Songini L (2007) Performance measurement systems in after-sales service: an integrated framework. Int J Bus Perform Manag 9:145-171

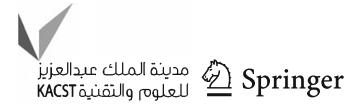


16. Goffin K, New C (2001) Customer support and new product development: an exploratory study. Int J Oper Prod Manag 21:354-373

17. Griffin J (1995) Customer loyalty: how to earn it, how to keep it. Lexington Books, New York

18. Halstead D, Page TJ Jr (1992) The effects of satisfaction and complaining behavior on consumers repurchase behavior. J Satisf Dissatisf Complain Behav 5:1-11

19. Hansemark OC, Albinsson M (2004) Customer satisfaction and retention: the experiences of individual employees, managing service quality. Int J 14:40-57

20. Heskett JL, Jones TO, Loveman GW, Sasser EW, Schlesinger L (1994) Putting the service-profit chain to work. Harvard Business Rev 72:164-174

21. Kahraman C, Cevik Onar S, Cebi S, Oztaysi B (2017) Extension of information axiom from ordinary to intuitionistic fuzzy sets: an application to search algorithm selection. Comput Ind Eng 105:348-361

22. Keiningham TL, Vavra TG (2001) The customer delight principle: exceeding customers' expectations for bottom-line success. McGraw Hill, New York

23. Kotler P, Keller KL (2012) Marketing management. Prentice-Hill, Harlow

24. Krishnan AR, Hari K (2011) Factors determining customer satisfaction in consumer durable white goods: factor analysis approach. Asia Pac J Res Bus Manag 2:32-46

25. Kurata H, Nam S (2010) After-sales service competition in a supply chain: optimization customer satisfaction level or profit or both? Int J Prod Econ 127(1):136-146

26. Lindgreen A, Davis R, Brodie RJ, Buchanan MO (2000) Pluralism in contemporary marketing practices. Int J Bank Mark 18:294-308

27. Matzler K, Sauerwein E (2002) The factor structure of customer satisfaction: an empirical test of the importance grid and the penalty-reward-contrast analysis. Int J Serv Ind Manag 13:314332

28. Parasuraman A, Zeithaml VA, Berry LL (1985) A conceptual model of service quality and its implications for future research. J Mark 49:41-50

29. Parasuraman A, Zeithaml VA, Berry LL (1988) SERVQUAL: a multiple-item scale for measuring consumer perceptions of service quality. J Retail 64:12-40
30. Reichheld F (1996) The loyalty effect: the hidden force behind growth, profits and lasting value. Harvard Business School Press, Boston

31. Reichheld FF, Sasser WE (1990) Zero defection: quality comes to services. Harward Business Rev 68:105-111

32. Rigopoulou ID, Chaniotakis IE, Lymperopoulos C, Siomkos GI (2008) After-sales service quality as an antecedent of customer satisfaction: the case of electronic appliances. Manag Serv Qual 18:512-527

33. Roig JCF, Garcia JS, Moliner MA (2009) Perceived value and customer loyalty in financial services. Serv Ind J 29:775-789

34. Sadeghi T, Hanzaee KH (2010) Customer satisfaction factors (CSFs) with online banking services in an Islamic country. J Islamic Mark 1:249-267

35. Shapiro M, Gomez MI (2014) Customer satisfaction and sales performance in wine tasting rooms. Int J Wine Bus Res 26:45-60

36. Szwejczewski M, Goffin K, Anagnostopoulos Z (2015) (2015) Product service systems, aftersales service and new product development. Int J Prod Res 53:5334-5353

37. Tse DK, Wilton PC (1998) Models of consumer satisfaction formation: an extention. J Mark Res 25:204-212

38. Vranakis S, Chatzaglou P, Mpaloukas A (2012) Customer satisfaction of Greek mobile phone services. Int J Manag Value Supply Chains 3:43-54

39. Wilson TL, Bostrom U, Lundin R (1999) Communications and expectations in after sales service provision: experiences of an international Swedish firm. Ind Mark Manage 28:381-394

40. Xu Z, Cai X (2012) Interval-valued intuitionistic fuzzy information aggregation. Springer, Berlin

41. Xu ZS, Yager R (2008) Dynamic intuitionistic fuzzy multiple attribute decision making. Int J Approx Reason 48:246-262

42. Yu D, Huchang L (2016) Visualization and quantitative research on intuitionistic fuzzy studies. J Intell Fuzzy Syst 30(6):3653-3663

43. Yu D, Shi S (2015) Researching the development of Atanassov intuitionistic fuzzy set: Using a citation network analysis. Appl Soft Comput 32(189-198):1568-4946

44. Zackariasson P, Wilson TL (2004) Internetworked after-sales service. Ind Mark Manage 33:75-86 